\title{
Correction to: Imaging \\ of the Stomach and Esophagus \\ Using CT and PET/CT Techniques
}

\author{
Ahmed Ba-Ssalamah, Sarah Poetter-Lang, \\ Nina Bastati, Jacqueline C. Hodge, Helmut Ringl, \\ and Richard M. Gore
}

\section{Correction to: Chapter "Imaging of the Stomach and Esophagus Using CT and PET/CT Techniques" in: Med Radiol Diagn Imaging (2018), https://doi.org/10.1007/174_2018_183}

Inadvertently, the chapter was published online without the source information for all the figures in this chapter.

The below source information has now been added in the figure caption of all the figures - Fig. 1 to Fig. 36.

"Published with kind permission of Medical University of Vienna 2019. All Rights Reserved" 